\title{
YUST-'ISIA

\section{Modern Slavery in Fishing Industry: the Need to Strengthen Law Enforcement and International Cooperation}

\author{
Aryuni Yuliantiningsih'; Jaco Barkhuizen ${ }^{2}$ \\ ${ }^{1}$ Faculty of Law, Universitas Jenderal Soedirman, Indonesia \\ ${ }^{2}$ Department of Criminology and Criminal Justice, \\ University of Limpopo, South Africa \\ Corresponding author's email: aryuni.yuliantiningsih@unsoed.ac.id
}

\begin{tabular}{l}
\hline Article Information \\
\hline Submitted : 09 December 2020 \\
Reviewed : 28 February 2021 \\
Accepted : 30 March 2021 \\
Keywords: \\
fishing industry; international \\
cooperation; law enforcement; \\
modern slavery \\
DoI: 10.20961/yustisia. \\
v10i1.46511
\end{tabular}

\begin{abstract}
The global fishing industry supports the livelihoods of millions. However, it adversely allows the occurrence of crimes throughout the value chain, especially modern slavery. This research aims to examine the current existence of slavery in the fishing industry for the state to determine the best way to deal with its repeated occurrence. The research method was a normative legal approach. The source of data uses secondary data collected through library research. Data was presented analytic descriptively. Studies show that slavery still exists due to the vulnerability of the fishing sector. These include the prolonged timeframe on board which prevents the crew from leaving the vessel, poor working conditions, the long-hours associated with the catching process, lack of access to authorities, use of foreign flags to create barriers to the law enforcement, use of migrant labor lacking representation and the lack of governmental oversight or support. This research states that it is important to combat modern slavery by strengthening law enforcement through compliance and deterrence involving the source, flag, coastal, port, trade, and market States. Beside it need for strengthening international cooperation between States and international organization.
\end{abstract}

\section{Introduction}

The fishing industry contributes immensely to global food security, human welfare, and economic prosperity, in addition, it is of great importance to the coastal communities in many developing countries $(F A O, 2012)$. This sector also aids in generating household income and employment throughout the supply chain (ARF, 2019). Unfortunately, unhealthy business competition and scarcity of fish resources have led to certain adverse

\begin{tabular}{ll|l}
\hline Yustisia Volume 10 Number 1 (Jan-Apr 2021) ～Modern Slavery in Fishing Industry: The Need... & $\mathbf{1}$
\end{tabular}


effects, namely illegal, unreported and unregulated fishing (IUUF), strengthening the practice of human trafficking, forced labour, and modern slavery (IOM, 2015). Initially, there was no general definition for modern slavery because it was generally referred to as persons subjected to gross exploitation or coerced by abuse of power, threats or violence, and restrained from leaving. This term encompasses of forced labour, human trafficking, and child marriage .

Modern slavery remains hugely prevalent, with an estimated 40.3 million men, women, and children enslaved globally (Migran info, 2019). In recent times, slavery has been hidden under at least two different forms: labour contracts and prostitution. (Mutaqin, 2018). Furthermore, illegal, unreported, and unregulated fishing is prevalent in Southeast Asia. According to the IUU fishing index carried out in 2019 by the Global Initiative against Transnational Organised Crime disclosed that Asia fared the worst among all fishing areas in the world. Cambodia, Vietnam, Myanmar, Philippines, and Indonesia are among the 15 countries that performed badly in the capture fisheries sector, as reported by the Asia Foundations, which revealed that overfishing had put 64 per cent of the total fisheries sector in Southeast Asia at "moderate-to-high risks."

There are several publications that examine modern slavery. Zainal Zezen Mutaqin has examined the modern slavery in the fishing industry which focuses on concept the modern day slavery and cases of human trafficking in Thailand. (Mutaqin, 2018) Besides, Melissa Marshcke and Peter Van der Gesst focused on the scandals about slave labour in the fisheries in Thailand and find that migrant workers are recruited in ways that often render them highly vulnerable to labour abuses.(Marschke \& Vandergeest, 2016). Furthermore Douglas Macfarlane examine about the right of visit under the Law of the Sea Convention related case of Exploitation in the Fishing Industry in New Zealand and Thailand. (MacFarlane, 2017).

Trafficking into the fishing industry is not new yet. It has gone largely unpunished for too many years. For example in the case of Benjina. The situation in Benjina and Ambon is symptomatic of a much broader and insidious trade in people, not only in the Indonesian and Thai fishing industries, but indeed globally. (IOM/KKP/Coventry University 1, 2015).

The failure of the international community to ratify instruments aimed at establishing minimum safety requirements for fishing vessels, combined with poor enforcement of existing regulations by flag states. Regulatory frameworks that address labour conditons aboard fisheries vessels have not been adopted, ratified or adequately enforced by the internatonal community. Based on this fact, it is urgent to propose the concept to address modern slavery in fishing industry.

This article aims to elaborate the causes factors why modern slavery does still exist and propose on the measures to curb the modern slavery. The author argues that it is necessary to strengthen law enforcement from countries involved in the fishing industry chain, namely coastal State, flag State, port State. and tradeState. In addition, international cooperation is needed to eradicate modern slavery because it is transnational crime. The legal theory used is the theory of Albert Reiss which states that law enforcement consists of two strategies, namely compliance and detention. (Reiss, 1984).

$2 \quad$ Yustisia Volume 10 Number 1 (Jan-Apr 2021) Modern Slavery in Fishing Industry: The Need... 


\section{Research Methods}

The type of research is normative juridical with statute approach. The data sources use secondary data include treaties, books and journal which related to modern slavery. The legal materials used by the authors in this study were obtained from the primary law material namely: United nations Convention on the Law of the Sea, United Nations Convention on Transnational organized Crime, ILO's Work in Fishing Convention, 2007 (No.188), ILO's Worst Forms of Child Labour Convention, 1999 (No. 182), The secondary data by examining library materials were presented descriptively which arranged systematically, logically and rationally qualitatively . (Soekanto, Soerjono and Mamudji, 2013)

\section{Research Result and Discussion}

\section{A. The Factors of Modern Slavery Still Exist in Fishing Industry}

The fishing industry is extremely vulnerable to the practice of modern slavery. The Environmental Justice Foundation (EJF), in a report entitled All at Sea, stated the occurrence of forced labour and human trafficking on board fishing boats in West Africa, and Asia. (International Labour Organisation, 2013). Subsequently, a research titled Caught at Sea, written by the ILO, also reported the existence of modern slavery in the fishing industry. (Environmental Justice Foundation, 2019).

The Associated Press investigation on slave-caught fish in the international food supply chain rapidly attracted The World-Check was attracted to the associated press investigation on slavery, as well as IUU fishing activities in the Arafura Sea (Associate Press, 2015). According to a report titled Blood and Water, which is based on Slavery in the Fishing Industry disclosed several detailed cases of abuse on vessels flying the flags of both developing and developed nations, from the E.U. and U.S. to Asia and South America . (Greenpeace \& Serikat Buruh Migran Indonesia, 2019). The journal entitled Seabound by the Green Peace, reported the occurrence of modern slavery on the high seas in Southeast Asia. (ILO, 2016). Based on these reports, forced labour and human trafficking are forms of modern slavery existent in the fishing industry.

In 2016, the Global Slavery Index (GSI) reported that fishing companies in Thailand failed to eradicate forced labour and other forms of slavery in their supply chains. There were approximately 425,500 illegal workers in the Thai fishing industry, which originated from Cambodia, Laos, and Myanmar, as well as exploit and deprive them of their freedom. (GSI, 2016). However, it occurs in several forms, and the commonest are human trafficking, forced labour, debt bondage, descent-based, and child slaveries (Webb, 2019). The International Labour Organisation ("ILO") defined forced labour as "services exacted or imposed on an individual or group of persons under any form of threat or penalty and for which they have not voluntarily offered themselves" (Caruana, Crane, Gold, \& LeBaron, 2021). 
The Anti-Slavery International defined modern slavery as the exploitation of victims that are deprived of their wisdom. A person is reported to be in slavery when :

1. Being coerced to work, either through verbal or physical threats;

2. Controlled by an employer, either through harassment, psychological or physical abuse;

3. Treated inhumanely, like a commodity, or property ; and

4. Deprived of their freedom. (Hosanee, 2009).

Presently, modern slavery is existent due to several factors, among others, reclusive and formidable activities occur at sea. The world oceans are subjected to the various jurisdictional regime. Subsequent factors include the inefficient and defective monitoring, restriction, and supervision carried out by coastal countries, particularly developing nations on fishing activities, and even ships flying their flags. This is further complicated by the practice of some fishing vessels registered in different countries asides from the nations that possess these ships. In addition, they are commonly referred to as the Flag of Convenience (FOCs) member countries, as reported by the International Transport Workers Federation (Greenpeace \& Serikat Buruh Migran Indonesia, 2019).

According to the report by Green Peace Southeast Asia, slavery is still existent because vulnerable job seekers from Indonesia and the Philippines keep trying their luck at jobs with better pay. Furthermore, labour agencies keep luring workers with false promises, with the rapid decline of fish populations, transshipment at sea, and lack of restrictions or support from the government. (Greenpeace \& Serikat Buruh Migran Indonesia, 2019).

Cheap and exploited labour tends to increase profits temporarily. However, overfishing reduces profitability in the long term, hinders economic development, including those that depend on this sector. This shows that there is a link between market demand, overexploitation, illegal fishing, and human trafficking, as emphasized by the EJF which stated that "the international demand for cheap seafood leads to the continuous brutal trafficking of vulnerable people as well as the destruction of the entire marine ecosystems" (EJF, Oceana, The Pew Trust, \& WWF, 2015).

Based on theories and causes of crime, an increase in demand is the triggering factor for the occurrence of transnational organised crimes in fisheries, and this is due to the shift in consumption of staple foods. Business actors in the fishery product supply chain are also expected to provide fish, regardless of the ways by which they are obtained, whether legally or illegally (Bondaroff, Van Der Werf, \& Reitano, 2015). Corporate crimes in the fisheries sector are triggered by the rational model theory put forward by Marshall B. Clinard \& Peter C. Yeager , which stated that the primary goal of business organizations is to realize large profits, which are usually achieved by violating the law.

Globalisation has led to an increase in the number of operators enlisting fishing vessels in the open registry to avoid criminal liability. Although, in the case of transnational operators, it is typical for a vessel suspected of being

$4 \quad$ Yustisia Volume 10 Number 1 (Jan-Apr 2021) ～Modern Slavery in Fishing Industry: The Need... 
involved in the slave trade to be registered in one country and operated in another. Consequently, the owner is based in a third country, while the crew members are citizens of a fourth and occasionally a fifth country.

The fishing industry's value chain typically consists of the following potential stages, which lead to modern slavery: preparatory, catching phase, fish landings and processing, transportation, exportation, and selling of fish products to consumers (Ewell et al., 2017).

a. Preparation Phase

The commonest crime at this stage is document fraud, a widespread offense in this sector, and it is because most fishing documentation is paperbased. Fraudulent and dishonest methods often recruit crew members. Document fraud includes the production of false documents concerning a ship's flag State registration or ownership and the vessel's name, dimensions, or identifiers. At this stage, the actor prepares the ship to be used for fishing activities. Besides, fishing companies tend to register vessels and recruit crew members through dishonest methods and, in some instances, violence.

b. Catching Phase

Human trafficking associated with the fishing industry, tend to occur in most developed countries worldwide. For instance, the trafficking of children for artisanship activities is socially acceptable in some areas in the form of forced labour. The problems associated with illegal fishing and those exploiting their crew members have been reported, which include physical and sexual abuse, coercion, negligence, poor working conditions, and thme occasional murder.

The process of transshipment has also been criticised as it leads to labour and human rights violations. Furthermore, regular resupply and offloading causes vessels to remain on the sea for months or even years, thereby imprisoning the crew members on board and making them vulnerable to abuse and exploitation.

c. Work Completion Phase

Immediately, the task is completed, the workers are either not paid or improperly rewarded. However, in the Long Xing case, 45 Indonesian crew members were owed the sum of 2.9 billion (APIL and EJF, 2020).

\section{B. The Measures to Curb the Modern Slavery in Fishing Industry}

This study proposes a the measures to tackle modern slavery in the fishing industry through strengthening law enforcement and international cooperation. The legal theory used is law enforcement theory according to Albert Reiss. He divides law enforcement into two strategies, namely emphasizing compliance and emphasizing detention through punishment. The purpose of law 
enforcement is through compliance by using tools to ensure compliance without having to impose criminal penalties on offenders. Meanwhile, the strategy of law enforcement with deterrence is to ensure compliance by means of detecting violations, determining the responsible party and punishing criminally to prevent further violations by the perpetrator or by the wider community (Aarons \& Rona, 2016).

1. The need to strengthen the law enforcement to combat modern slavery in fishing industry

The first strategy of law enforcement through the complience international law that have been ratified by States. Generally, the prohibition of slavery has been regulated by several international instruments, such as

a. The establishment of 1926 Slavery Convention on concrete rules and articles to suppress slave trade.

b. Article 4 of the Universal Declaration of Human Rights, stated that "no one needs to be enslaved, all forms of slavery are prohibited."

c. The right not to be enslaved is stipulated in Article 1 of the International Convention on Civil and Political Rights (ICCPR).

Prohibition of modern slavery as regards the condition of work in the fishing industry is regulated by

a. In 1930 and 1957, two fundamental Conventions were adopted by the ILO on forced labour. In the first with No. 29, members attempted to suppress all forms of slavery in the shortest possible period. Furthermore, the ILO's Abolition of Forced Labour Convention (No. 105) was utilized during the peak of the Cold War, which emphasized on the immediate eradication of slavery. The state exacted this convention for economic and political purposes in accordance with Article 3(a) of ILO's Worst Forms of Child Labour Convention, 1999 (No. 182). This law stated that all forms of slavery or similar practices, such as child trafficking, serfdom, debt bondage, and coercion which are regarded as the 'worst forms of child labour'.

b. ILO's Work in Fishing Convention, 2007 (No.188)

This law binds the requirements needed to address the primary issues associated with jobs on fishing vessels. These include occupational safety, medical and health care, social security, work agreements, and rest periods. It is aimed at ensuring that fishing vessels are properly constructed and maintained to provide decent living conditions on board .

States that have ratified ILO Conventions authorized ships which vessel with their flags to comply with the following rules:

i. The owner of the fishing vessel is absolutely responsible for ensuring that the skipper is provided with the necessary resources and facilities to comply with this Convention's obligations. 
ii. The skipper's responsibility is to ascertain the safe operation of the vessel and the fishers.

iii. The minimum age for working on a fishing vessel is a basic requirement that needs to be met. In addition, the workers' health and period of rest need to be guaranteed.

c. IMO International Convention on Standards of Training, Certification, and Watch Keeping for Fishing Vessel Personnel, 1995.

d. Protocols to Prevent, Suppress, and Punish Traffickers, Particularly Women and Children trafficking, supplementing the United Nations Convention against Transnational Organised Crime (UNTOC), 2000

This aimed to provide a comprehensive legal framework and facilitate global partnerships to investigate and prosecute human trafficking. Consequently, the Protocol was designed to provide protection and assistance to victims of trafficking.

Based on compliance approach, States should carry out the obligations in international treaties on slavery that have been ratified. Additionally, entering into treaties entrusts States with the responsibility to respect, protect, and fulfil these rights. The obligation to respect simply implies that States need to refrain from interfering with or curtailing human rights' benefits. The responsibility to protect requires States to ascertain the protection of individuals and groups against abuses, while the obligation to fulfil means that they need to take positive action to facilitate the benefits of human rights (Santosa, 2016).

The second strategy of the law enforcement through deterrence and punishment impose. The legal consequences of ratification leads to the implementation in the internal law by the Government. The domestic legal system provides the principal protection of human rights, which is guaranteed by international law. However the proceedings fail to address human rights abuses, the mechanisms and procedures are provided at the regional and international levels to ensure the universal human rights standards are respected, implemented, and locally enforced.

The States need to be able to enforce the laws and punish the perpetrators and offer protection to the victims of modern slavery. The efforts to prevent and combat human trafficking is carried out by the $4 \mathrm{P}$ paradigm, which is reported as follows:

a. Prosecution: Human Trafficking is one of the transnational organised crimes in UNTOC. Therefore, there is a need for the existence of international cooperation between States during the enforcement of the law to combat human trafficking by sharing evidence, testimonial admission, and collaboration database. Furthermore, differences in the jurisdiction and legal system need not be considered as an obstacle.

b. Protection: Courses that aid in developing law enforcement officers' capacity regarding the typologies and modus operandi of human rights violations committed in the fishing business need to be carried out in 
the ports. This understanding is necessary to streamline the judge's actions towards handling human trafficking.

c. Prevention: The Government needs to comply with human rights because it is a condition that permits fishing efforts, its capture, and transportation. This is assessed by the implementation of human rights due to diligence audits. Companies that comply and possess the certification of human rights are entitled to carry out business activities on fisheries

d. Partnership: Creating consumer awareness concerning the importance of fisheries products complies with human rights. "Money tend to buy numerous things, however it need not be able to buy another human being." (Santosa, 2016).

Modern slavery in the fishing industry is a transnational crime, in which there is a need for international cooperation. A crime is termed transnational when it occurs in (a) it more than one country, (b) a particular country with a significant part used to prepare, plan, direct or control the activities that occur, (c) a certain country although byan organised criminal group, or (d) a specific country with primary effect on another. A certain form of modern slavery is human trafficking, and it is a transnational crime, as regulated by the UNTOC.

National law enforcement against slavery encounters obstacles, thereby requiring cooperation between internal and international legal institutions through:

a. The ILO and United Nations supervisory mechanism

The ILO periodically reviews the reports of the member states on labour standards, investigates complaints through the Ad hoc Commissions of Inquiry, and is endowed with the power to impose sanctions whenever the recommendations are unable to be fulfilled. UN supervisory special rapporteur is mandated by the Human Rights Council to promote international legal norms and standards concerning slavery in countries and foreign organisations. Finally, the rapporteur reports the findings and offers recommendations to the Human right Council.

b. Regional human rights mechanism

Law enforcement is also carried out through regional mechanisms. Conversely, the Organisation for Security and Co-operation in Europe (OSCE) and Central Asia plays a significant role. The OSCE also provides a model for strategic coordination and the promotion of norms. Its Special Representative and Coordinator for Combating Human Trafficking is in charge of all the tasks in the organisation(Greenpeace \& Serikat Buruh Migran Indonesia, 2019), for instance, the Economic Community of Africa punished Niger for its failure to prevent slavery as regulated in Article 5 of the African Charter in the case of Hadijatu Mani V Niger (Duffy, 2009). 
c. Corporate Compliance and Prevention Initiative

Companies are also responsible for preventing human rights violations in the industry. The corporate responsibility to respect (RtR) simply means that business entities need to avoid human rights violations as well as overcome the negative impacts they have on humans. In addition, companies have access to remedy (AtR), and this is an aspect of their obligation to offer human rights protection against violations relating to certain businesses. Therefore, States need to take appropriate steps, through judicial, administrative, statutory, or other appropriate measures, in order to ensure that when violations occur in their territory or jurisdiction, the affected parties have access to effective recovery. (OHCR, 2012).

In addition to these mechanisms, the principles of State responsibility are applied in modern slavery. They include source, flag, coastal,port, trade, and market States. The source States are those recruit and transit fishers subjected to forced labour. This kind of State is a preparatory phase that ensures that the qualifications are supported with adequate education and training. Migrant fishers are at higher risk of being exploited and abused in several countries. However, immediately after signing a work agreement with the agent in the country of origin A, the prospective fishermen proceeds across the border, agent $B$ takes them to the ship in country $C$, owned by $\mathrm{D}$, while flying the flag of $\mathrm{E}$. In most cases, the fishermen either board the ship or are abandoned at the port of country F. (International Labour Organisation, 2013).

The flag states are also responsible for addressing modern slavery. Therefore, they need to exercise their jurisdiction over social matters on vessels, as stated in Article 94 (1) of UNCLOS. Unfortunately, some countries are unwilling to meet their obligations under international law. This is because many of them are not members of the international legal frameworks established to protect fishers at sea. In addition, the inadequate "genuine link" between ship owners and flags, specified in article 91 of UNCLOS, makes it tedious for them to exercise jurisdiction over a company. A genuine link means that a ship owner is accountable for violations of international law in accordance with the assets and resources of a flag state (Rothwell, et all., 2015). Flag States are members of ILO committed to criminalizing and combating forced labour, and human trafficking. They also ratify parties to the ILO Forced Labour Convention or the United Nations Protocol to Prevent Human Trafficking. In addition, their primary responsibility at sea is to ensure compliance with international and national laws on vessels flying their flags.

The absence of this leads to a new form of responsibility. The port State ensures that every vessel that arrives in the harbor satisfies its rules and regulations. Prior to this, Port State Control (PSC) regimes accepted some international minimum labour standards. The adoption of the Merchant Shipping such as Minimum Standards was in accordance with the 1976 (No. 
147) convention. This was also in line with the most recent Maritime Labour Convention, 2006 which was ratified by States in August 2013, thereby, leading to an increased focus on the working conditions of merchants. Therefore, port States play an essential role in detecting labour exploitation and abuse with the occasional lack of transportation by fishermen without means of repatriation.

During transshipment or discharge of catch, fishers' abuses are most likely to be identified in port States by harbour authorities, including fisheries and labour inspectors. PSC has become an effective tool to ensure compliance with international safety regulations and labour standards in merchant shipping and is carried out through a regionally coordinated regime by means of several Memoranda of Understanding (MOUs). These MOUs enforce a uniform system of PSC throughout the membership region, and information is shared among members, inspection targets are realized, and cooperation during implementation. Unfortunately, fishing vessels are not included in these regional MOU arrangements.

Also, a coastal State regulates and controls all the tasks carried out on the fishing vessels when they are in their territorial sea (within 12 nautical miles of the baselines along its coast) or, in relation to fishing activities, in the EEZ (a maximum of 200 nautical miles from the baselines). The Coastal States have the right to issue fishing licenses to vessels within their EEZs , and an aspect of it includes stipulations on the nationality of fishers on board in addition to their working and living conditions

The safety instrument systems at sea that are used to enhance transparency in the fisheries sector, tend to facilitate intelligence, while tracing, inspecting, investigating, and prosecuting vessels and operators engaged in forced labour and human trafficking. Furthermore, the regulatory activities with certification compliance are used to inspect vessels at the port. Coastal States need to establish agencies and units dedicated to PSC.

Trade and market States also play a role in preventing slavery. European Union is extremely concerned about human rights violations in Thailand's fishing industry. On the $22^{\text {nd }}$ of April 2015, the EU sanctioned Thailand after disclosing the case of slavery in Benjina. They were issued a yellow card, and the importation of fishery products into the country was restricted (TRefor, 2015).

Forced labour and human trafficking can be combated through enhanced regulation and implementation control of safety and labour standards. Furthermore, several binding legal instruments have been established by ILO and the International Maritime Organisation (IMO) to improve fishermens safety and working conditions. For instance the ILO's Work in Fishing Convention (No. 188), Certification and Watch keeping for Fishing Vessel Personnel (TCW-F), the IMO's Torremolinos Protocol, Convention on Standards of Trading, as well as non-binding recommendations and codes, developed between the ILO, Food and Agriculture Organization

$10 \quad$ Yustisia Volume 10 Number 1 (Jan-Apr 2021) Modern Slavery in Fishing Industry: The Need... 
(FAO) and IMO. Besides the STCW-F, none of the binding legal instruments was restricted from March 2013. The slow pace of conventional ratification, which inhibits the effective flag and port, controls the safety and labour standards in the fishing industry. It also undermines important opportunities to prevent and detect instances of human trafficking and forced labour on vessels. Subsequently, the absence of binding legal frameworks also contributes to lack of transparency concerning the information on vessel ownership, identity, and movement.

\section{The Need to Strengthen International Cooperation to counter modern slavery in fishing industry}

International cooperation is conditio cine qua non to enforce the modern slavery because it has transnational character relating to the nature of transnational crime that involving two or more jurisdictions. (Muladi, 2016).

In addition to strengthening law enforcement, international cooperation is also necessary to tackle slavery in the fishing industry. There are transnational characteristics that involve the jurisdictions of two or more countries. The transnational aspect of modern slavery in this sector is derived from various elements such as the vessel's flag, the coastal waters where the crimes occurs, the port where illegal catches are landed, the nationality of operators, and companies, as well as the import or export state of the commodities. This multiplicity of jurisdictions is needed for effective cooperation of the different States and administrations during the prevention, investigation, and prosecution stages (OECD, 2013)

Cooperation in international law enforcement tends to informally occur during an official investigation through arrangement made between the relevant police agencies that are permissible under national laws. Strengthening international legal cooperation is realized through mutual legal assistance and extradition, as well as bringing perpetrators to justice by applying stringent penalties consistent with legal obligations This is boosted both regionally and internationally by, facilitating effective datasharing, supporting foreign legal cooperation during investigations and prosecutions, destroying safe havens for criminals, exchanging exceptional ideas collaboration based on the victims' identification, protection, reintegration and repatriation, and the provision of appropriate technical and financial support to partners.

The cooperation instruments regulated by the UNTOC framework include the exchange of prisoners, Mutual Legal Assistance (MLA), and extradition. In principle, Article 16 of the UNTOC stated that this Convention is used as a legal basis for the extradition of perpetrators, particularly when no treaty applies between the participating countries. In fact, it further stated that criminal offenses encompassed by the provisions of this Convention need to be defined as extraditable offenses in treaties formed between member states . 
The cooperation instrument "MLA" is a means or forum to assist countries in carrying out investigations and prosecutions of criminal cases involving two or more countries. Mutual assistance in criminal matters is a cooperative mechanism that enables various countries to produce evidence directly and efficiently. (Ginting, 2012). The MLA is broader than the legal extradition remedies because, in States, it seeks to uphold jurisdiction over criminals, it also strengthens efforts to eradicate, prevent and punish them, based on the cooperation of other countries. (Elliot, 2016).

Furthermore, another collaboration mechanism is carried out through a joint investigative team (JIT). It is established for a fixed period, and this team comprises of law enforcement officers from various countries that are trained to jointly investigate transnational cases. Several international instruments have reiterated competent authorities to inaugurate "joint investigative bodies" through multilateral or bilateral agreements concerning certain matters.

Additionally, no international organisation is devoted to modern slavery. However, the following list comprises a number of organisations that participate in crime related activities in the fishing industry.

a. INTERPOL

A project scale was launched by INTERPOL in 2013, which acts as a global inefficient and defective monitoring, restriction, and supervision carried out by coastal countries form for combating illegal fishing and criminal related activities. It was renamed Global Fisheries Enforcement, and the role is to identify, deter, and disrupt transnational fisheries crimes (Environmental Justice Foundation, 2015). Interpol issues purple notices to member countries in order to describe the method often used to employ and transport unsuspecting workers to aquaculture sites, where they are abused and exploited. Some of the structures and methods used by criminals, are agents, travel agencies, recruitment, fish processing industries, vessel and company owners, etc.

b. United Nations on Drugs and Crime (UNODC)

An analytical, normative, and fieldwork research was carried out by the UNODC to assist States in understanding crime related issues, in order to implement international treaties. UNODC carried out two vast studies on the "Transnational Organised Crime in the Fishing Industry

c. Organisation for Economic Co-operation and Development (OECD)

The Organisation for Economic Co-operation and Development (OECD) on fisheries focuses on developing a sustainable economy and fighting tax crime.

d. The International Labour Organisation (ILO)

In 2007, the ILO adopted the Fishing Convention (No. 188) relating to the working conditions in this sector. The ILO launched a Sea Project aimed

12 Yustisia Volume 10 Number 1 (Jan-Apr 2021) Modern Slavery in Fishing Industry: The Need... 
to strengthen coordination. Its primary objective is to decrease the number of human trafficking in the fishing industry by increasing the effectiveness and efficiency of the existing national and regional levels of anti-trafficking efforts in Southeast Asia .

e. The International Maritime Organisation (IMO)

In 1987, IMO introduced a Ship Identification Number Scheme to assist in the prevention of fraud, while enhancing the security and safety of the merchant vessel fleet. (IMO, 2017).

Strengthening law enforcement and international cooperation to eradicate modern slavery in the fishing industry involving the state and international organizations. Countries that need to strengthen law enforcement include coastal states, flag states, port countries and flag states. International cooperation is carried out between countries or countries with international organizations through bilateral or multilateral agreements.

\section{Conclusion}

Presently, modern slavery is still in existence due to various factors, including workers, individuals, countries, and companies. Employees lack the ability to communicate, and they are encouraged to earn high incomes. Companies seek maximum profit by exploiting labour. The government does not supervise these recruiting firms; in addition, ships sailing on the high seas are not monitored. Therefore, it is necessary to strengthen law enforcement and international cooperation to eradicate modern slavery. The measures to strengten the law enforcement can be carry out through compliance and deterrence theory. The states yang telah meratifikasi perjanjian internasional terkait dengan slavery mempunyai kewajiban untuk menimplementasikan dalam ukum nasional. The state which has the responsibility to strenghten the law enforcement to tackle the modern slavery in the fishing industry are the coastal or source State, flag State, port State, and trade State. In addition, it is necessary to strengthen international cooperation between States, and States with international or regional organizations under UNTOC framework.

\section{BIBLIOGRAPHY:}

\section{Books:}

Bondaroff, Theale.( 2015). The Illegal Fishing And Organized Crime Nexus: Illegal fishing As Transnational Organized Crime. Switzerland: Global Initiative Against Transnational Organized Crime and The Black Fish.

CoCayne, James (2015).Why We Need a Global Partnership to end modern slavery, UN University.

Donald R. Rothwell, et. al., (2015) The Oxford Handbook of the Law of the Sea, Oxford University Press.

Lorainne Elliot and William H. Schaedla, (2016). Handbook of Transnational Environmental Crime, Edward Elgar Publisihing. 
Muladi dan Dyah Sulistyani RS. ( 2016). Kompleksitas Perkembangan Tindak Pidana dan Kebijakan Kriminal. Bandung: PT Alumni.

Santosa, Mas Achmad, (2016). Alam pun Butuh Hukum dan Keadilan, Prima Pustaka: Jakarta.

Soerjono Soekanto dan Sri Mahmudji, (2013). Penelitian Hukum Normatif, Suatu Tinjauan Singkat. Jakarta: Raja Grafindo Persada.

OHCR, (2012). The Corporate Responsibility To Respect Human Rights, New York: United Nations.

Karp, David Jason, (2020). What is the Responsibility to Respect Human Rights? Reconsidering the 'Respect, Protect, and Fulfill' Framework, March Vol 12.

Interpol, Project Scale, (2017). Modern Slavery in The Fishing Industry, Seafish Seafood Ethics Common Language Group.

\section{Journals and others}

Albert J. Reiss Jr., (1984) Consequences of Compliance and Deterrence Models of Law Enforcement for the Exercise of Police Discretion, 47 Law and Contemporary Problems, Vol 47 No. 4. 83-122.

Caruana et. al . (2000) Modern Slavery in Business: The Sad and Sorry State of a NonField , Business $\mathcal{E}$ Society 00(0).

Diana Bulan Hampton, (2019). Modern Slavery in Global Supply Chains: Can National Action Plans on Business and Human Rights Close the Governance Gap? Business and Human rights Journal, vol 4 issue 2.

Duffy, (2009). Helen Hadijatou Mani Koroua v Niger:Slavery Unveiled by the ECOWAS Court, Human Right Law Reveiw 9.

Ewel, Cristopher. et. al.,(2017). Potential Ecological and Social Benefits of a Moratorium on Transshipment on the High Seas, Marine Policy, 81.

EJF,(2015). Pirates and Slaves: How Overfishing in Thailand Fuels Human Trafficking and the Plundering of Our Oceans.

Ginting, J. (2012) . "Roles of Mutual Legal Assistances and Extradition of Assets Recovery in Indonesia ", Jurnal Hukum Internasional Vol. 9.( 4 ).

Hosanee, N. M. (2009). A Critical Analysis Of Flag State Duties As Laid Down Under Article 94 Of The 1982 United Nations Convention On The Law Of The Sea, The United Nations-Nippon Foundation Fellowship. programme 2009 - 2010 Division for Ocean affairs and the law of the sea office of legal affairs, the New York: United Nations.

Interpol, (2018). International Law Enforcement Cooperation in Fisheries Sector, A Guide for Law Enforcement Practitioners.

ILO, (2015). International Expert Meeting on Labour Exploitation in the Fishing Sector in the Atlantic region.

$14 \quad$ Yustisia Volume 10 Number 1 (Jan-Apr 2021) Modern Slavery in Fishing Industry: The Need... 
Meere, Frank and Mary Lack, (2008). Assessment of Impacts of Illegal, Unreported and Unregulated (IUU) Fishing in the Asia-Pacific, Asia-Pacific Economic Cooperation Fisheries Working Group.

Mutaqin, Zezen Z. (2018). Modern-day Slavery at Sea: Human Trafficking in the Thai Fishing Industry, Journal East Asia and International Law, 11 (2).

Web, Pilippa and Garciandia, Rosanna, (2019). State Responsibility For Modern Slavery: Uncovering and Bridging the gap, International and Comparative Law Quartely, 68(3).

Rona , Gabor,\& Lauren Aarons (2016), State Responsibility to Respect, Protect and Fulfill Human Rights Obligations in Cyberspace, Journal National and Policy, Vol 8 p. 1-33

Mahmud Syalyout. (2012). “Laporan Akhir Kompendium Hukum tentang Kerjasama Internasional di Bidang Penegakan Hukum". Jakarta: BPHN.

Melissa Marschkea and Peter Vandergeestba, (2016). Slavery Scandals: Unpacking labour Challenges and policy responseswithin the off-shorefisheries sector Marine Policy, Vol. 68. 39-46

ILO, Fishers Fish, (2016). Good Practices to End Labour Exploitation of Sea, International Labour Organization.

\section{Web site}

APIL and EJF,(2020). A Briefing on Longxing 629:A case of illegal, unreported and unregulated (IUU) fishing activities and related human rights abuses on a tuna longliner, available from https://foeasiapacific.org/2020/07/23/a-briefing-onlongxing-629/ (Accessed on Oct, 3, 2020).

Interpol Launches Project Scale to Combat Fisheries Crime, available at https://www. interpol .int/en/News-and-Events/ News/ 2013/INTERPOL-launches-ProjectScale-to-combat-fisheries-crime (Accessed on Oct, 3, 2020)

Moss, TRefor, (2015), EU Puts Thailand on the Hook Over Illegal Fishing available online from https://www.wsj.com/articles/eu-puts-thailand-on-the-hook-over-illegalfishing-1429610655 (Accessed on Oct, 15, 2020)

Blood and Water. Human rights abuse in the global seafood industry (2019) available online from https://www.migra-info.org/2019/07/ 03/blood-and-water-humanrights-abuse-in-the-global-seafood-industry/ (Accessed on Jul. 3, 2020).

ILO, Sea Fisheries Project available from https://www.ilo.org/jakarta/whatwedo/ projects/WCMS_566916/lang--en/index. htm (Accessed on Oct, 3, 2020)

IMO Ship Identification Number Scheme, available at http://www. imo.org/en/ ourwork/ msas/pages/imo- identification-number -scheme.aspx (Accessed on Oct.12, 2020).

OECD, Combating Tax Crime and Other Crimes in the Fisheries Sector, available at http://www.oecd.org/agriculture/ (Accesed on Aug 2, 2020). 